\title{
THE CREATION OF THE INTEGRATED NATURAL GAS MARKET IN THE BALTIC REGION AND ITS LEGAL IMPLICATIONS
}

\author{
L. Zemite*, A. Ansone, L. Jansons, I. Bode, E. Dzelzitis, \\ A. Selickis, A. Romanovs, L. Vempere \\ Riga Technical University, \\ Faculty of Electrical and Environmental Engineering, \\ Institute of Power Engineering \\ 12-1 Azenes Str., Riga, LV-1048, LATVIA \\ *e-mail: laila.zemite@rtu.Iv
}

A common natural gas market in the Baltic region, which is in operation since 1 January 2020, means a single entry-exit tariff system for the natural gas transmission among Finland, Estonia, Latvia, and a common Latvian-Estonian balancing zone. Finland joined the market with a separate balancing zone, certain rules, contracts, invoices and billing, with a decision for full integration to be taken not earlier than in 2022. Lithuania is not currently the common market participant, because it is not ready to join it with such revenue splitting conditions as Finland, Estonia and Latvia. But still common entry-exit tariff zone countries are actively working to find a viable solution for market expansion. Lithuania and other neighbouring Member States of the European Union (hereinafter - the EU), first and foremost, Poland, are welcome to join.

The creation of an integrated regional natural gas market in the Baltics in the long term will stimulate the interest of traders in the region, strengthen security of supply and improve market liquidity. Increased market competition, predictable prices in the long term, transparent tariffs, digital communication and customer-oriented business strategies are just a small part of benefits that will inevitably develop with time.

Keywords: BEMIP, Finland, legal implications, natural gas market, RGMCG, the Baltic region. 
Natural gas is one of the most widely used energy resources in the world, as it is considered to be the cleanest one of conventional fossil fuels. Historically, since its introduction in the early 1960s, it has always played an important role in the energy supply of the Baltic region, including Latvia. The Latvian natural gas market comprises approximately $35 \%$ of the natural gas market in the three Baltic States [1], and in a mid-term perspective natural gas is considered to be an important low carbon energy resource to ensure smooth transition to carbon neutrality both on the national and regional scale [2].

The EU takes a strong position in the global fight against climate change by setting ambitious targets on reduction of greenhouse gas (hereinafter - GHG) emissions. A binding target is to reduce those emissions by at least $40 \%$ below 1990 levels till 2030, which would help make Europe the first climate neutral continent by the mid-21st century. Consequently, the expected 2050 GHG emission reduction target for the EU is $80 \%-90 \%$ below 1990 levels [3]. This could be achieved by turning climate and environmental challenges into opportunities across all policy areas and making the energy transition just and inclusive for all. Despite contradictive status and clear fossil nature of the natural gas, its sustainable use can still be a key factor in the EU gradual and cost-effective transition to carbon neutrality [4], [5].

The European Commission"s (hereinafter - the EC) Strategy for Energy System Integration, published in July 2020, states that the natural gas will still account for about $20 \%$ of gaseous fuels used in the EU by 2050, as a true percentage of biogas, biomethane, hydrogen or synthetic gases in its primary energy mix by that time is hard to predict precisely [6]. However, with the EC's hoping for greater electrification in the region, it anticipates that overall natural gas demand will fall to below 630 terawatt-hours (hereinafter - TWh) by 2050 in comparison with $5222 \mathrm{TWh}$ in 2019. The strategy identifies carbon capture and storage as one of the ways for natural gas to fit into the European ambitious climate-neutrality objectives, and sets a clear path for natural gas as a bridge fuel to more intensive use of the renewable gases [6], [7].

Despite the fact that overall regressive trend in the natural gas consumption has been dominant in the Baltic region over the past two decades, the share of natural gas in total primary energy consumption of Latvia has never reached a level below $21 \%$. According to the data of the Central Statistical Bureau of the Republic of Latvia (hereinafter - the CSB), in 2010 $31.5 \%$ and in $201924.3 \%$ of the total primary energy consumption came from natural gas [8].

The drop of about $6 \%$ was due to an increasing share of switch to alternative fuels in centralised heat production and growing political support of the renewable energy sources. However, as CSB data also indicate, in almost ten years (2010-2018) a decline of the natural gas consumption in Latvia has not been significantly sharp. However, at the same time, the total decrease in the natural gas consumption in the three Baltic States between 2010 and 2018 reached about $25 \%$, of which the biggest share was attributable to Lithuania [1]. 


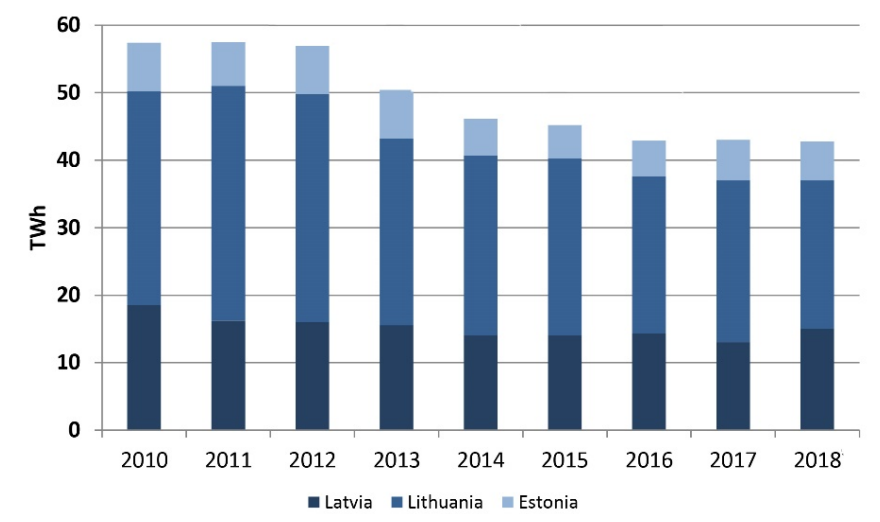

Source: Central Statistical Bureau of Latvia, ENTSOG, Amber Grid

Fig. 1. Natural gas demand in the Baltic States, TWh (2010-2018).

In a wider regional scale, a role of the natural gas as a transitional fuel would rise, as many EU Member States, including Finland, are airing plans for coal phase-out in energy production in the upcoming decade. On 19 March 2020, the Finnish Government issued a decree on investment aid for projects accelerating the replacement of coal in energy production. The aid is intended to promote voluntary phase-out of coal use by the end of 2025. At the same time, the ban of coal-based power and heat generation will take effect in the country from 1 May 12029 [9].

Such a decision is important for both rising Finland's level of energy efficiency and sustainability, and further development of the regional natural gas market, with obvious potential for an increase in the natural gas consumption in at least midterm perspective.

\section{TOWARDS LIBERALIZATION OF THE BALTIC NATURAL GAS MARKET}

In 2015, the EC adopted the Energy Union Strategy based on five key targets, which incorporate market objectives as well as put in place the guidelines of the common EU energy policy [10]. The Energy Security Strategy addresses measures both for shortterm security, mainly focusing on resilience to energy supply disruptions, and for long-term security - diversification of energy supply and finally reduction of energy dependency on external energy supplies. The aims of the common energy policy include ensuring the functioning energy market and security of energy supply by diversification of energy sources and promoting interconnection of all Member States' energy networks [11].
Even before the Energy Union Strategy was launched, the EU energy market liberalization packages, adopted in 1998, 2003 and 2009, have been at the centre of the common gas market creation in the EU. With the adoption of relevant directives and regulations, the EC set a goal to finalize (with a few exceptions) the internal energy market by 2014, notably, by enforcing the unbundling of networks away from the competitive parts of the electricity and gas businesses. The EU Third Energy Package mandated the EU Member States to unbundle the natural gas and electricity distribution networks: transmission should be separated from supply and distribution. This should done to reduce the 
monopoly power possession risks of single or several energy market actors [12].

To achieve this goal, the EU Third Energy Package provided three options for unbundling: ownership unbundling, establishment of the Independent System Operator or creation of the Independent Transmission System Operator. Lithuania was among the first countries that implemented the Third Energy Package and adopted the strictest option - ownership unbundling [13]. Following Lithuania's decision, Estonia implemented its unbundling legislation. Latvia, on the other hand, postponed the implementation until April 2017. Even after unbundling finalization in Latvia, in Finland fully stateowned natural gas company "Gasum Oy" remained a vertically integrated company and the major market player in the Finnish natural gas industry. The company thus continued to perform various market roles: it was the only market participant importing natural gas to Finland, acted as the natural gas transmission operator (hereinafter -TSO), whilst also operating in the segments of the natural gas transport and trade, complemented by its subsidiary "Kaasupörssi Oy".

The work and achievements of regional cooperation in the energy sector in the Baltic Sea region has been conducted within the framework of the Baltic Energy Market Interconnection Plan (hereinafter - BEMIP) initiative, which was launched in 2009. The main goal of the BEMIP initiative, within the context of the EU's 20-20-20 objectives and beyond, was full integration of the three Baltic States - Lithuania, Latvia and Estonia - into the European energy market, through the strengthening of interconnections with their EU neighbouring countries [14]. The BEMIP initiative was further reinforced through reforms launched by the EC at the BEMIP High Level Group (hereinafter HLG) meeting on 31 October 2014 and the Declaration on Energy Security of Supply (hereinafter - Declaration) signed on 15 January 2015 by the energy ministers of the Baltic States [15].

The BEMIP has been successful, since Estonia, Latvia, and Lithuania have developed electricity interconnections both between themselves and to other parts of the EU [11].

Another part of the BEMIP concerned plans to build pipelines between Poland and Lithuania, and Finland and Estonia to interconnect the natural gas systems and integrate the natural gas markets of these countries. This task is partially fulfilled - the natural gas interconnector between Estonia and Finland - Balticonnector, has been in operation since 1 January 2020 - the same day, when the common Baltic and Finnish natural gas market platform was launched [16]. In turn, the Lithuanian-Polish natural gas interconnector GIPL is expected to be ready for exploitation in 2022.
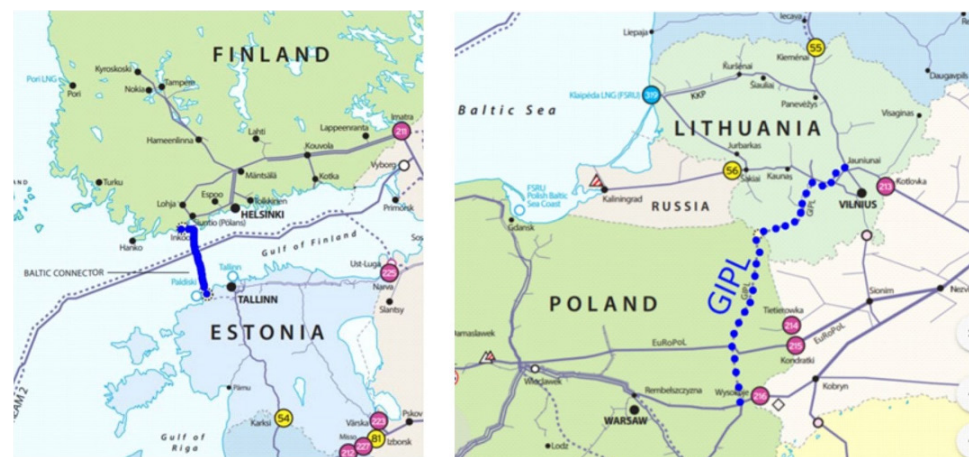

Source: entsog.eu

Fig. 2. Routes of Balticconnector (left), and GIPL (right). 
As for December of 2020, in Lithuania, more than $50 \%$ of the pipeline construction works were finalized. In summer of last year, the interconnecting pipeline was laid down under the two widest rivers in Lithuania, using the environmentally-friendly horizontal directional drilling technology. After testing the pipeline at maximum pressure and installing the starting point of the pipeline, the first part of GIPL was connected to the operating gas transmission system and filled with natural gas. In Poland, the construction of the pipeline is divided into two sections (northern and southern) and works are ongoing to build the northern section, which is approximately $185 \mathrm{~km}$ long. In addition, the two TSOs launched a nonbinding survey procedure for development of services for new transmission capacity in GIPL in November 2020 [17].

\section{THE NATURAL GAS MARKET INTEGRATION TRENDS AND THE REGIONAL GAS MARKET COORDINATION GROUP}

The Baltic States have always been dependent on one dominant natural gas supplier and have also been isolated from the European natural gas networks in terms of the natural gas transmission infrastructure. In order to prevent rising energy dependency of the EU as a whole and further physical isolation of certain segments of the energy sector of particular Member States, the EC decided to gradually liberalize the natural gas markets.

The First Energy Package was adopted more than 20 years ago in 1998, with the Second Package following soon after - in 2003. Further liberalization of the natural gas markets came in April 2009, when the Third Energy Package was adopted, providing the basis for the completion of the internal energy markets and ending of monopoly state. The Third Energy Package consisted of several documents, two of which: Directive 2009/73/EC of the European Parliament and of the Council concerning common rules for the internal market in natural gas and repealing Directive 2003/55/EC (hereinafter - Directive 2009/73/EC) [18] and Regulation (EC) No. 715/2009 of the European Parliament and of the Council on conditions for access to the natural gas transmission networks and repealing Reg- ulation (EC) No 1775/2005 (hereinafter - Regulation 715/2009) [19], concern the natural gas markets.

Considering the support from the EC and national agreement within the Baltic Sea region, in October 2008, the EC set up HLG, including representatives of Denmark, Germany, Estonia, Latvia, Lithuania, Poland, Finland and Sweden [20]. Norway participated in the group as an observer.

In June 2009, this group came up with the BEMIP, which embraced certain tasks in order to achieve both national and regional goals: namely, integration of the regional electricity and natural gas markets, and thus ending the isolation of the Baltic electricity and natural gas sectors from the rest of Europe.

At the end of 2014, the Prime Ministers of the Baltic States met in Tallinn, Estonia, and jointly agreed that it was essential to ensure implementation of the Third Energy Package. As the consequence of this decision, in January 2015, the Declaration was signed by the Baltic Energy Ministers. In this document, the signing parties committed themselves to develop a transparent, competitive and fully functioning regional natural gas and electricity market through the implementation of the Third Energy 
Package. Among others, this included the establishment of a Regional Gas Market Coordination Group (hereinafter - the RGMCG) and the decision to invite Finland to participate in the market [15].

The RGMCG was established to promote the opening of the national natural gas markets, to develop an action plan for the development of a regional natural gas market, to promote an efficient functioning common regional natural gas market in the Baltic States, and to develop measures to ensure the Baltic natural gas market physical connection with Finland.

It was agreed that the common natural gas market platform would deliver a number of benefits, such as efficiently transported and stable natural gas flows, the most economically advantageous natural gas price offers, greater market liquidity, where previously contractual congestion would otherwise limit gas flows in certain market areas and improve security of supply. Also, economic consultants from the United Kingdom's Frontier Economics found in its 2016 study that, inter alia, a single market area would bring benefits and overall prosperity to the region compared to isolated, small areas [21].

Regular cooperation within the RGMCG was ensured with participation of responsible ministries, national regulatory authorities and the natural gas transmission system operators (hereinafter - TSOs) of the three Baltic States and Finland. The main objective of this group was to create a common and fully functional Finnish-Baltic natural gas market by outlining attractive market conditions for existing and new market players, ensuring free access to the advantages of the region's largest natural gas infrastructure and to strengthen security of the natural gas supply.

RGMCG meetings were held several times a year to monitor progress, provide support and solutions to problems encountered, and to guide further processes towards the goal of establishing a common gas market. Meetings were held on a rotating basis each year, mainly in the ministries of the Baltic States. In 2019, Latvia was the leading country organising RGMCG meetings, but in 2020 meetings were planned to be held in Estonia.

To ensure that actions of RGMCG are coordinated and target oriented, in June 2015 the RGMCG approved short-term and medium-term action plan that included measures to:

- develop non-discriminatory, transparent and flexible access rules for gas transmission systems and storage within the regulatory framework;

- harmonise requirements related to the natural gas quality;

- discuss issues regarding financing of Projects of Common Interest (hereinafter - PCI);

- harmonise energy measuring units and other parameters.

The involvement of Finland in the implementation of the plans was voluntary and not mandatory, taking into account derogation based on Directive 2009/73/EC and Regulation $715 / 2009$. Finland was equally active and involved in common market development as the Baltic States, expressing its readiness to be part of the common gas market.

Well-developed infrastructure plays a key role in creation of a strong and truly integrated market. GIPL, Balticconnector and the development of interconnectivity capacities within the Baltic States themselves are the main natural gas infrastructure projects important for the establishment and proper functionality of the common gas market and the implementation of the BEMIP. 


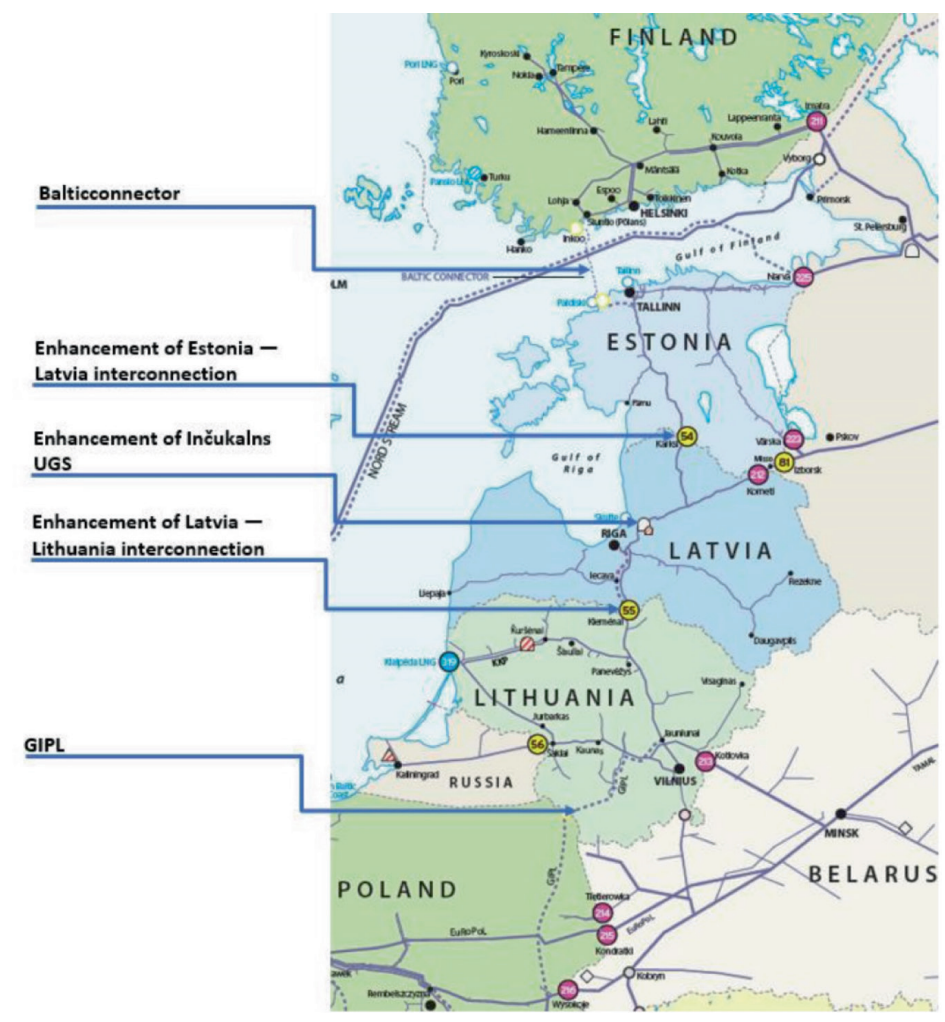

Source: The Latvian Public Utilities Commission

Fig. 2. PCI in the Baltic Region.

Since creation of the RGMCG, progress has been made in all aspects to develop a common natural gas market. Regulatory authorities of the Baltic States, together with TSOs and responsible ministries, have continued to harmonise and develop a transparent and non-discriminatory variety of rules and processes, including the adoption of common principles for the use of the natural gas transmission system. Discussing progress on short-term and medium- term goals and taking into account the main tasks, in 2016 the RGMCG presented the Regional Gas Market Action Plan with the main tasks to be accomplished by 2020. Accordingly, on December 2016, the Baltic prime ministers signed a Declaration on the Development of the Regional Gas Market, welcoming the Regional Gas Market Action Plan and inviting Finland to continue its successful cooperation in the process of establishing the market.

\section{RULES OF OPERATION OF A COMMON NATURAL GAS MARKET}

In October 2018, the natural gas TSOs of Finland, Estonia and Latvia signed a common Memorandum of Understanding (hereinafter-MoU), stating their preparedness to do anything that is necessary to cre- ate a common gas market by 2020 . Unfortunately, Lithuania did not sign the MoU and was not ready to agree to join with the same conditions as Finland, Estonia and Latvia (hereinafter - FINESTLAT). Lithuania 
wanted to apply for exceptions in relation to GIPL and Klaipeda liquefied natural gas (hereinafter - LNG) terminal, while having trouble accepting Inter TSO Compensation Mechanism that was agreed by other involved parties.

In February 2019, FINESTLAT TSOs singed Inter TSO Compensation (hereinafter - ITC) agreement, which enabled the functioning of a single gas transmission tariff zone for Finland, Estonia and Latvia from the beginning of 2020. ITC mechanism intended to combine revenues from entry points and share them by the national natural gas consumption after deducting TSO variable costs related to facilitation of regional flows.

Taking into account contributions made by all countries to the market development, from 1 January 2020 Finland, Estonia and Latvia have a single entry-exit tariff area and Estonia - Latvia - common balancing zone. As for now, Finland has a separate balancing zone with separate terms, contracts, bills and settlements, but after 2022 it will face the next big energy market decision on whether to fully join the EstonianLatvian balancing zone or not. As Estonia and Latvia also have a common balancing area with common network rules, it means that by signing an agreement with either Latvian or Estonian natural gas TSO, system user has automatic access to the transmission infrastructure of both countries.

New unified system balancing rules developed for a common natural gas market were submitted to the Latvian Public Utilities Commission and the Estonian Competition Council on 29 May 2019 for taking a coordinated decision [22].

Also, the development of tailor-made solutions for the natural gas trading was intended to contribute to increased liquidity, competitiveness and transparency of wholesale gas markets in the Eastern Baltic region. "GET Baltic" market platform operates as a licensed natural gas market operator with the status of Registered Reporting Mechanism provided by the European Union Agency for the Cooperation of Energy Regulators. It administrates the electronic trading system for trading spot and forward natural gas products with physical delivery in the market areas located in Lithuania, Latvia, Estonia and Finland [23].

\section{A COMMON NATURAL GAS MARKET AND THE NATIONAL LEGAL FRAMEWORK}

The creation of a regional natural gas market was related to and directly influenced by national energy legislations of both the Baltic States and Finland. One of the most important tasks for the responsible

\subsection{Finland}

Finland's processes were different from the rest of the Baltic States, since Finland was preparing not only for becoming part of a common entry-exit tariff zone with Esto- ministries within the RGMCG Action Plan was to amend the legislation and prepare grounds for common natural gas market inauguration in the early 2020.

nia and Latvia, but also it needed to make major legislation changes to ensure smooth and timely natural gas market liberalization. The access rules to the transmission 
system and the internal market rules came into force, by which "Gasum Oy" gas transmission function was separated from the natural gas sales.

Already in January 2018, the new Finnish Natural Gas Market Act (hereinafter the Act) came into force, and, as of March of 2019, the Finnish Government called for the need of its amendments, which were directly related to the establishment of a common natural gas market. Among others, amendments included new rules allowing for transmission tariff flexibility to ensure end of Finland's energy isolation and to allow Finland to be part of common entryexit tariff system, which included two or more EU Member States. The reform of the natural gas market in the long term plans a number of specific legislative changes to facilitate the development of the single natural gas market by extending the powers of both the Finnish natural gas TSO and the national regulatory authority regarding regional tariff agreements and regional entry-exit tariff system. Consequently, Finland's readiness to carry out such a significant reform of the natural gas sector, which concerns both market liberalization and the unbundling of the transmission system operator, as well as support and readiness to engage in regional market creation processes through appropriate preparation of the national regulatory framework, was highly valued by market participants, other countries and the EC.

The purpose of the Act was to ensure the conditions for a national and regional natural gas market that would function efficiently, securely and environmentally sustainably as well as for the EU's internal natural gas market. The aim is to ensure good security of supply of natural gas and access to natural gas that is competitively priced and sufficiently high in quality. The primary means for creating a functioning natural gas market are safeguarding healthy and effective economic competition in the supply and storage of the natural gas, and maintaining reasonable and fair service principles in the functioning of natural gas networks and LNG processing facilities. The tasks of enterprises in the natural gas sector include ensuring the provision of services relating to their customers' natural gas procurement and promoting in their own and their customers' activities the efficient and economic use of natural gas. The Act applies to the import, export, transmission, distribution, delivery and storage of natural gas and LNG. In addition, the provisions of the Act cover the gases from renewable energy sources and other gases that can be technically and safely injected into the natural gas network and transmitted and distributed within it [24].

Currently, the Finnish natural gas system is run by "Gasgrid Finland Oy", a new company unbundled from "Gasum Oy" [25]. The natural gas transmission system operations were ownership unbundled from electricity and natural gas generation and supply. A new natural gas TSO "Gasgrid Finland $\mathrm{Oy}$ " was unbundled through a partial demerger from "Gasum Oy" that entered into force on 1 January 2020. Furthermore, on the same date, the ownership of transmission system operation was transferred to the Ministry of Finance of Finland. "Gasgrid Finland Oy" submitted its application for the certification of the TSO to the Finnish Energy Authority in January 2020, with subsequent positive decision made by the Authority in May 2020. Then it was submitted to the EC for the final approval. On 2 July 2020, the approval was received and the certification of "Gasgrid Finland Oy" was finalized [26]. 


\subsection{Estonia}

In Estonia, establishment of a common natural gas market was made by single amendment in the Estonian Natural Gas Act [27]. It was done in Paragraph 9, Section 2 of the Act, which was related to a pricing of the natural gas. The Act was amended in a manner that the entry tariff might be included in the natural gas pricing. These legislative changes were drafted by the Ministry of Economic Affairs and Communications of Estonia, in cooperation with the national regulatory authority, TSO and natural gas traders. No objection was raised by any of the parties involved and the legislative changes were made very easily by

\subsection{Lithuania}

In Lithuania, the year 2018 ended with quite extensive amendments to the Law on Natural Gas of Lithuania [29]. In several aspects, these amendments were related to the development of a common natural gas market, despite the fact that Lithuania had not been part of the common market area yet. These amendments gave mandate to the Lithuanian Government to make a decision to join a common natural gas market after evaluating conclusions on economic benefits for consumers made by the Ministry of Energy of the Republic of Lithuania and the National Commission for Energy Control and Prices (hereinafter - the NCECP). Therefore, when there is a common decision made, it will be possible for Lithuania to join the market immediately. At the same time, TSO was given a mandate to review the transfer of balancing function to a common regional natural gas market operator -

\subsection{Latvia}

In Latvia, on 23 February 2016, amendments to the Energy Law (hereinafter - the EL) concerning opening of the natural gas adding them to other amendments already in the first reading.

In all, the Estonian Natural Gas Act has always been relatively flexible, without creating restrictions on new market processes. Within the Estonian legal framework, the Competition Authority cannot influence the import and/or supply prices, which are formed on a contractual basis. However, the Authority can verify whether the seller of natural gas follows law and sells natural gas to all consumers on equal conditions and does not abuse its position in the market [28].

a new legal entity jointly created by common gas market TSOs and acting as a "onestop shop" for balancing services in the entire region. The NCECP received power to approve the inter-operator agreement mechanism, if submitted by TSOs as well.

Both the Lithuanian natural gas TSO $\mathrm{AB}$ "Amber Grid" and the national regulatory authority participated in the development of appropriate amendments. There were no objections to the purpose of these amendments, and the Lithuanian Parliament gave them almost unanimous support. For a few legal aspects, for example, uncertainty about how the market will be regulated and supervised in a common entry-exit tariff zone, the parties and responsible ministry and regulatory authority held intensive discussions with government lawyers, so that these amendments would be accepted [29].

market and division conditions of JSC Latvijas Gāze were approved by the Parliament. The amendment of the EL provided 
that by 3 April 3 2017, JSC Latvijas Gāze would haveto be divided, and a distinction had to be made between the natural gas transportation and storage, and distribution and trading functions. On 22 December 2016, common natural transportation and storage operator JSC Conexus Baltic Grid was established [30]. The creation of single natural gas distribution system operator JSC Gaso followed on 22 November 2017 [31].

To ensure full functionality of a common natural gas market, on 1 January, 2020 it was essential to amend the national Energy Law. Amendments were needed for all parties to have clear definitions, responsibilities and obligations in the new market situation. Also, there was a need to empower the Latvian National Regulatory Authority - the Public Utilities Commission (hereinafter - the PUC), to approve new gas transmission tariffs for the whole new market area.

In October 2020, amendments to the Energy Law, removing obstacles to the development of a common natural gas market with Estonia and Finland, came into force. According to the mandate given, the PUC was now able to approve the network and balancing rules, as well as transmission tariffs, and make decisions that had crossborder effects.

\section{CONCLUSION}

When assessing the creation of a common natural gas market in the Baltic States and Finland, it can be concluded that the integration processes both from technical, regulatory, political and legal viewpoints were managed and carried out successfully.

In particular, during all the managerial stages of integration, the RGMCG has proven itself as an efficient cooperation platform, which has brought the professionals, politicians and lawyers of the natural gas sector together to discuss and solve the problems. The creation of a common gas market in the Eastern Baltic showed that its impact on the national legislation depended on a complexity of existing natural gas related regulations, but in general it did not cause any significant burden for the national legislations of the involved parties.

The integration of the Baltic-Finnish natural gas market brought novelties to the natural gas exchange platform "GET Baltic" as well. On 1 January 2020, it successfully launched a new market area in Finland becoming a single regional trading platform for the Baltic-Finnish natural gas market. Due to the merger of the Latvian and Estonian natural gas markets, the market areas were also merged on the natural gas exchange into one common market area. Finally, together with expanding its activities, continuous trading opportunities were ensured: trading on "GET Baltic" takes place around-the-clock. These and many other changes implemented during 2020 led to grown market interest and activity on the natural gas exchange and the Baltic-Finnish common natural gas market as a whole [23].

Close cooperation for addressing major challenges on the way to creation a common natural gas market united all involved parties and led to a unique and beneficial result - the creation of the EU's first truly transnational natural gas market platform. For the future, it is planned to expand common entry-exit tariff zone and balancing zone in the neighbouring countries, with other significant tasks including increasing sustainability of the natural gas infrastructure being on their way. 
The research has been supported by the National Research Programme, project "Trends, Challenges and Solutions of Latvian Gas Infrastructure Development" (LAGAS) (No. VPP-EMINFRA-2018/1-0003).

\section{REFERENCES}

1. Groblinghoff, S. (2019). The Future of the Energy Sector - Challenges and Opportunities. Bull or Bear? Outlook for natural gas demand in the Baltic region. Available at https://lg.lv/uploads/documents/2019-0304_Presentation-Energetika-2019Conference_-S.Groeblinghoff_LG_FINAL. pdf

2. Krukowska, E. (2021). Europe Kicks the Can on Defining Role for Natural Gas in a Clean Energy Transition. Available at https://www. worldoil.com/news/2021/4/15/europekicks-the-can-on-defining-role-for-naturalgas-in-a-clean-energy-transition

3. 2030 Climate Target Plan. (n.d.) Available at https://ec.europa.eu/clima/policies/euclimate-action/2030_ctp_en

4. Savickis, J., Zemite, L., Zeltins, N., Bode, I., \& Jansons, L. (2020). The Natural Gas and Biomethane in the European Road Transport: The Latvian Perspective. Latvian Journal of Physics and Technical Sciences, 57 (3), 57-72. DOI: 10.2478/lpts-2020-0016

5. Communication from the Commission to the European Parliament, the European Council, the Council, the European Economic and Social Committee and the Committee of the Regions. The European Green Deal. Available athttps://ec.europa. eu/info/sites/info/files/european-green-dealcommunication-annex-roadmap_en.pdf

6. Communication from the Commission to the European Parliament, the European Council, the Council, the European Economic and Social Committee and the Committee of the Regions. Powering a climate-neutral economy: An EU Strategy for Energy System Integration. Available at https://eur-lex.europa.eu/legal-content/EN/ ALL/?uri=COM:2020:299:FIN
7. Ernhede, C. (2020). Letter from Brussels: Gas still Fuelling EU's Green Transition. Available at https://www.petroleumeconomist.com/articles/low-carbon-energy/ energy-transition/2020/letter-from-brusselsgas-still-fuelling-eus-green-transition

8. Latvijas statistikas gadagrāmata. (2020). Available at https://www.csb.gov.lv/lv/ statistika/statistikas-temas/ekonomika/ $\mathrm{ikp} /$ meklet-tema/400-latvijas-statistikasgadagramata-2020

9. Investment incentives to promote rapid phase-out of coal in energy production.(n.d.). Available at https://valtioneuvosto.fi/en//1410877/asetuksella-investointikannustehiilen-energiakaytosta-ripeasti-luopuville

10. Communication From the Commission to the European Parliament, the Council, the European Economic and Social Committee, the Committee of the Regions and the European Investment Bank. A Framework Strategy for a Resilient Energy Union with a Forward-Looking Climate Change Policy. (n.d.). Available at https:// eur-lex.europa.eu/legal-content/EN/ TXT/?uri=COM:2015:80:FIN

11. Hermanson, A. S. (2018). Energy Security in a Multi-Level Governance Perspective. Marine Policy, 98, 301-308.

12. Growitsch, C., \& Stronzik, M. (2014). Ownership Unbundling of Natural Gas Transmission Networks: Empirical Evidence. Journal of Regulatory Economy, 46. https://doi.org/10.1007/s11149-0149252-0

13. Molis, A. (2016). Towards a Regional Gas Market in the Baltic States: Political, Economic and Legal Aspects. Humanities and Social Sciences Latvia, 24 (1). 
14. Ministry of Energy of the Republic of Lithuania. (n.d.). Regional Cooperation. Available at https://enmin.lrv.lt/en/sectoralpolicy/regional-cooperation

15. Elering. (n.d.). PA Energy - BEMIP Action Plan (for competitive, secure and sustainable energy). Available at https:// elering.ee/sites/default/files/attachments/ Action_Plan_FINAL_DG\%20REGIO.PDF

16. Latvijas Gāze. (2020). Balticconnector The Baltic Gas Market is Open. Available at https://lg.lv/en/news/balticconnector-atv\% C4\%93rts-baltijas-g\%C4\%81zes-tirgus

17. INEA. (2020). Gas Interconnector PolandLithuania: Works in Progress. Available at https://ec.europa.eu/inea/en/news-events/ newsroom/gas-interconnector-polandlithuania-works-progress

18. Directive 2009/73/EC of the European Parliament and of the Council of 13 July 2009 concerning common rules for the internal market in natural gas and repealing Directive 2003/55/EC. Available at https:// eur-lex.europa.eu/legal-content/EN/ALL/? uri $=$ CELEX\%3A32009L0073

19. Regulation (EC) No $715 / 2009$ of the European Parliament and of the Council of 13 July 2009 on conditions for access to the natural gas transmission networks and repealing Regulation (EC) No 1775/2005. Available at https://eur-lex.europa.eu/ legal-content/EN/ALL/?uri=celex\% 3A32009R0715

20. The Baltic Energy Market Interconnection Plan (BEMIP). (n.d.). Available at https://ec.europa.eu/energy/en/topics/ infrastructure/high-level-groups/balticenergy-market-interconnection-plan

21. Frontier Economics. (2016). Baltic Regional Gas Market Study. Final report. Available at http://basrec.net/wp-content/uploads/2017/ 02/Baltic-gas-market-study-2016.pdf

22. Conexus Baltic Grid. (n.d.). What is the Single Gas Market? Available at https:// www.conexus.lv/single-gas-market/kas-irvienotais-gazes-tirgus
23. Regional Gas Exchange GET Baltic has Launched New Market Area in Finland. (2020). Available at https://www.getbaltic. com/en/news/regional-gas-exchange-getbaltic-has-launched-new-market-area-infinland-2/

24. Gasgrid Finland. (n.d.). Legislation and Regulation. Available at https://gasgrid.fi/ en/gas-market/legislation-and-regulation/

25. The Government of Finland. (2019). Finnish Gas Market Opens up. Available at https:// valtioneuvosto.fi/en/artikkeli/-/asset publisher/10616/suomen-kaasumarkkinaavautuu

26. Energy Authority. (2019). National Report 2019 to the Agency for the Cooperation of Energy Regulators and to the European Commission. Finland. Available at https:// energiavirasto.fi/documents/11120570/ 13026619/National+Report+2020+Finland. pdf/7fb2df66-cf5e-ecf5-22a2-635077b6297a/ National+Report+2020+Finland.pdf? $\mathrm{t}=$ 1594791637682

27. Natural Gas Act (Estonia). Available at https:// www.riigiteataja.ee/en/eli/520032019006/ consolide\#para9

28. The Republic of Estonia Competition Authority. (2021). Electricity and Gas Markets in Estonia 2019-2020. Available at https://www.konkurentsiamet.ee/sites/ default/files/euroopa aruanne-loplik tolge_en_140421_.pdf

29. The Republic of Lithuania. (n.d.). Law on Natural Gas. Available at https://eseimas.1rs.lt/portal/legalAct/lt/TAD/ a1674c4002d211e9a017f05dde6559c6

30. Conexus Baltic Grid. (2017). Information for Latvian Natural Gas Market Participants. Available at https://www.conexus.lv//currentevents/informacija-latvijas-dabasgazestirgus-dalibniekiem

31. GASO. (n.d.). Uznēemuma vēsture. Available at https://www.gaso.lv/uznemuma-rasanas 